\title{
MicroRNAs in Vitis vinifera cv. Chardonnay Are Differentially Expressed in Response to Diaporthe Species
}

\author{
Ales Eichmeier ${ }^{1, * \mathbb{D}}$, Tomas Kiss ${ }^{1}$, Eliska Penazova ${ }^{1}$, Jakub Pecenka ${ }^{1}$, Akila Berraf-Tebbal ${ }^{1}$, \\ Miroslav Baranek ${ }^{1}$, Robert Pokluda ${ }^{1} \mathbb{D}$, Jana Cechova ${ }^{1}$, David Gramaje ${ }^{2}$ and \\ Dariusz Grzebelus ${ }^{1,3}$ (D) \\ 1 Faculty of Horticulture, Mendeleum-Institute of Genetics, Mendel University in Brno, Valticka 334, \\ 69144 Lednice, Czech Republic; tomas.kiss@mendelu.cz (T.K.); eliska.penazova@mendelu.cz (E.P.); \\ jakub.pecenka@mendelu.cz (J.P.); berraf.a@hotmail.fr (A.B.-T.); miroslav.baranek@mendelu.cz (M.B.); \\ robert.pokluda@mendelu.cz (R.P.); jana.cechova@mendelu.cz (J.C.); d.grzebelus@ogr.ur.krakow.pl (D.G.) \\ 2 Instituto de Ciencias de la Vid y del Vino (ICVV), Consejo Superior de Investigaciones \\ Científicas-Universidad de la Rioja-Gobierno de La Rioja, Ctra. de Burgos Km. 6, 26007 Logroño, Spain; \\ david.gramaje@icvv.es \\ 3 Department of Plant Biology and Biotechnology, Faculty of Biotechnology and Horticulture, \\ University of Agriculture in Krakow, 31425 Krakow, Poland \\ * Correspondence: ales.eichmeier@mendelu.cz; Tel.: +420-519367315
}

Received: 11 October 2019; Accepted: 5 November 2019; Published: 7 November 2019

\begin{abstract}
Diaporthe species are important pathogens, saprobes, and endophytes on grapevines. Several species are known, either as agents of pre- or post-harvest infections, as causal agents of many relevant diseases, including swelling arm, trunk cankers, leaf spots, root and fruit rots, wilts, and cane bleaching. A growing body of evidence exists that a class of small non-coding endogenous RNAs, known as microRNAs (miRNAs), play an important role in post-transcriptional gene regulation, during plant development and responses to biotic and abiotic stresses. In this study, we explored differentially expressed miRNAs in response to Diaporthe eres and Diaporthe bohemiae infection in Vitis vinifera cv. Chardonnay under in vitro conditions. We used computational methods to predict putative miRNA targets in order to explore the involvement of possible pathogen response pathways. We identified 136 known and 41 new miRNA sequence variants, likely generated through post-transcriptional modifications. In the Diaporthe eres treatment, 61 known and 17 new miRNAs were identified while in the Diaporthe bohemiae treatment, 101 known and 21 new miRNAs were revealed. Our results contribute to further understanding the role miRNAs play during plant pathogenesis, which is possibly crucial in understanding disease symptom development in grapevines infected by $D$. eres and D. bohemiae.
\end{abstract}

Keywords: high-throughput sequencing; grapevine; RT-qPCR; miRNA

\section{Introduction}

The genus Diaporthe (Sordariomycetes, Diaporthales, Diaporthaceae) is an extremely diverse and important group of fungi. It was proposed by Nitschke in 1870, with Diaporthe eres as the type species. This genus includes species that are pathogens, endophytes, and saprobes on hundreds of host plants, comprising agricultural crops, ornamental plants, and fruit and forest trees [1-4]. Diaporthe species are considered causal agents of grapevine trunk diseases [5]. Several species are well-known pathogens worldwide and are responsible for losses on a broad range of plants and economically important 
crops, including almond, apple, camellia, citrus, cucurbits, eggplant, grapevine, sunflower, peach, pear, persea, plum, soybean, and cranberries [3,6-18].

Numerous species have been described as causal agents of pre- or post-harvest infections. They are responsible for different disease symptoms, such as swelling arm, trunk cankers, leaf spots, rots, wilts, and cane bleeding [3,19-23]. Interestingly, many Diaporthe species can occur at the same time on diverse hosts or even on the same host or lesion [19,21,24,25].

Species in this genus are important pathogens of grapevine, causing cankers and other dieback symptoms in all major viticulture regions worldwide [24,26]. Several studies reported D. ampelina (=Phomopsis viticola) as the main species associated with Phomopsis cane and leaf spot all over the world. However, other Diaporthe species also have the ability to produce severe symptoms on grapevine, including D. eres, D. ambigua, D. foeniculina, D. amygdali, D. australafricana, D. baccae, D. celeris, D. eres, D. foeniculina (as D. neotheicola), D. helianthi, D. hispaniae, D. hongkongensis, D. hungariae, D. kyushuensis, D. perjuncta, D. phaseolorum, D. rudis, and D. sojae $[4,24,26,27]$. Their pathogenicity on grapevine has been confirmed on detached shoots, with a high variability in virulence $[4,19,27]$. However, certain environmental factors may accentuate or reduce the pathogenicity of the fungi. In addition, a high diversity of Diaporthe species observed in diseased vines does not exclude the possibility of a synergistic action of several species in causing disease. Moreover, this variability in virulence could be explained by the fact that plants produce many secondary metabolites, some of which have antimicrobial properties and may protect the plant against attacks [28]. For instance, grapevine develops various mechanisms at a physiological and molecular level in order to cope with the difficulties with biotic and abiotic factors in their environment [29]. Important progress has been made to understand plant-pathogen interactions and the multiple gene regulatory systems that they use during plant defense responses. Axenic cultivation of Diaporthe spp. allows direct in vivo investigation of molecular interactions postulated to exist between Diaporthe spp. and their plant hosts [14]. Additionally, high-throughput sequencing (HTS) of transcriptomes, as well as proteomics, has served as a valuable approach to gain new insights into physiological, biochemical, and molecular mechanisms underlying Diaporthe spp. disease symptom development in other plant species, such as asperge (Asparagus spp.) or rice [30-32].

A class of small non-coding endogenous RNAs known as microRNAs (miRNAs) plays a major role in post-transcriptional gene regulation during plant development and plant responses to biotic and abiotic stresses $[33,34]$. Mature miRNAs are typically 19 to $24 \mathrm{nt}$ in length and originate from miRNA (MIR) genes that are transcribed by RNA polymerase II. The transcripts, known as primary miRNAs (pri-miRNA), form imperfect fold-back hairpins that are cleaved by RNase III-like Dicer 1 (DCL1) to produce miRNA precursors (pre-miRNA). Each pre-miRNA contains one or more short intermediate complementary miRNA/miRNA duplexes [35]. These duplexes are then cleaved by DCL1 from the stem region and processed inside the nucleus to be exported to the cytoplasm, where the leading miRNA is incorporated into the RNA-induced silencing complex (RISC). When associated with RISC, guided binding of the miRNA to its complementary target mRNA(s) or non-coding trans-acting siRNA (TAS) transcript(s) occurs [33]. This facilitates either translational inhibition or degradation of target mRNA(s) or slicing of TAS transcripts that leads to generation of trans-acting siRNAs (tasiRNAs). Target degradation occurs through endonucleolytic cleavage by the RISC core protein Argonaute 1 (AGO1) [36-38]. The mechanism of RNA silencing in plants is also used in advanced detection techniques of viruses [39].

It has been suggested that the miRNA pathway contributes to pathogen-associated molecular pattern (PAMP)-triggered immunity (PTI), which refers to a basal defense response upon recognition of certain pathogenic elements. To date, the miRNA defense responses in Arabidopsis, rice, and a broad plant host range infected by pathogenic fungus have been evaluated [40-42], but none of these studies have been performed on the interaction of grapevine-trunk disease (GTD) pathogens.

The availability of two drafts of $V$. vinifera cv. Pinot Noir genome sequences obtained from high-throughput data $[43,44]$ has enabled rapid discovery of miRNAs that further supports the efforts to explore small RNA (sRNA)-based regulatory networks in grapevine. Computational analyses of 
high-throughput sequencing data, followed by experimental validation, have been used to identify highly conserved miRNAs, some of which play important roles in grapevine development $[45,46]$. To date, 186 mature grapevine miRNA sequences from 47 different miRNA families have been deposited in miRbase: the microRNA database [47].

Here, we hypothesized that $D$. eres, as a well-known GTD pathogen, would trigger a strong response of the miRNA machinery while $D$. bohemiae, described as non-pathogenic on grapevine, would not markedly enhance the expression of miRNAs associated with disease symptoms. We used computational resources for the in silico prediction and annotation of putative miRNA targets to explore the involvement of possible pathogen response pathways. An understanding the sRNA-mediated gene regulation may be crucial to the understanding of gene regulatory pathways involved in a range of stress-regulated physiological processes. Our results provide insight into miRNA-mediated pathogenesis in $V$. vinifera and may uncover new disease control strategies for molecular breeding.

\section{Materials and Methods}

\subsection{Plant Material}

Cultivar Chardonnay clone CHAR PO-156/4 was used in this study. Shoots were sampled at the end of the growing season in 2018 and buds with meristems were used for in vitro micropropagation. In vitro cultures were established using nodal segments grown on the Murashige and Skoog medium containing $1.33 \mu \mathrm{M}$ 6-benzylaminopurine (BA) and $0.57 \mu \mathrm{M}$ indole-3-acetic acid (IAA). The cultures were maintained at $23{ }^{\circ} \mathrm{C}$ with a $16 / 8 \mathrm{~h}$ cycle of light and dark. The experimental plantlets were transferred to a fresh medium after three weeks. Each plantlet was placed into a separate cultivation vessel. Six-week-old cultures were rooted on the MS medium with $0.81 \mu \mathrm{M}$ naphtalene acetic acid (NAA) [48]. We used in vitro plants because we hypothesized that a less influenced environment would be reached by using controlled abiotic and biotic factors compared to in vivo.

\subsection{Fungal Isolates}

Single-spore isolates of D. bohemiae strain CBS 143347 and D. eres strain CPC 28220 were used in this study. These two species were isolated from grapevine showing GTD symptoms in the Czech Republic [4]. The isolates were placed on potato dextrose agar (PDA) and cultivated for 10 days at $25^{\circ} \mathrm{C}$ in the dark.

\subsection{Plant Inoculation}

Trials were conducted on six-week-old rooted vines. Leaves of plantlets were inoculated with a 3-mm plug of 10-day-old cultures of either D. bohemiae (DB) or D. eres (DE) using sterile plastic tips. Leaves of control plants $(C)$ were inoculated with uncolonized sterile PDA plugs. One leaf per plant was inoculated and five plants per treatment were used. The experiment was repeated after two weeks.

\subsection{RNA Extraction and Quality Control}

RNAs were extracted from all inoculated and control plants 10 days after inoculation using PureLink $^{\mathrm{TM}}$ Plant RNA Reagent (Thermo Fisher Scientific, Waltham, MA, USA), according to the manufacturer's instructions. The total RNA yield and quality were measured using a Bioanalyzer 2100 (Agilent Technologies, Palo Alto, CA, USA) using the Agilent RNA 6000 Nano Kit and Modulus ${ }^{\mathrm{TM}}$ Single Tube Multimode Reader (Turner Biosystems, Sunnyvale, CA, USA) using the Quant-iT ${ }^{\text {TM }}$ RNA Assay Kit (Thermo Fisher Scientific, Waltham, MA, USA). Samples with an RNA Integrity Number (RIN) below 7 were excluded from further analysis. Only RNA concentrations higher than $5 \mathrm{ng} \mathrm{LL}^{-1}$ were used, and all samples at higher concentrations were diluted to $5 \mathrm{ng} \mu \mathrm{L}^{-1}$ based on fluorimetry. After RNA quantification, samples were pooled in groups according to the variant of inoculation, resulting in a total of five replicates per variant. 


\subsection{Library Preparation and Sequencing}

A small RNA library was constructed using the TruSeq small RNA library preparation kit (Illumina, San Diego, CA, USA) and purification was done with the TailorCut Gel Extraction Tool Set (SeqMatic, Fremont, CA, USA). The quality and quantity of the library were determined using the Agilent High Sensitivity DNA Kit (Agilent, Santa Clara, CA, USA). The quantity of libraries was also determined by a Modulus ${ }^{\text {TM }}$ Single Tube Multimode Reader (Turner Biosystems, Sunnyvale, CA, USA) using a Quant-iT ${ }^{\mathrm{TM}}$ dsDNA Assay Kit (Thermo Fisher Scientific, Waltham, MA, USA) and finally with a MCNext ${ }^{\mathrm{TM}}$ SYBR ${ }^{\circledR}$ Fast qPCR Library Quantification Kit (MCLAB, San Francisco, CA, USA) used with Rotor-Gene 3000 (Corbett Research, Sydney, Australia). All the kits were used according to the manufacturer's instructions. The libraries were pooled according to fluorimetry as $2 \mathrm{nM}$, supposing that the final small RNA fragments were $\sim 150 \mathrm{bp}$.

For the sequencing run, a final pooled library of small RNAs consisted of three pooled samples/variants per one run. Sample C was labelled with index RPI5 (ACAGTG), sample DB with index RPI6 (GCCAAT), and sample DE with index RPI7 (CAGATC). The second run with repetitions also consisted of three pooled samples. Sample $C$ was labeled with index RPI12 (CTTGTA), DB with index RPI10 (TAGCTT), and DE with index RPI11 (GGCTAC).

The libraries were sequenced with the MiniSeq instrument (Illumina, San Diego, CA, USA) using the MiniSeq High Output Reagent Kit, 75-cycles (Illumina, San Diego, CA, USA) providing 36-nt long reads.

\subsection{Bioinformatics and Data Evaluation}

The MiniSeq reads were demultiplexed using the Illumina bcl2fastq2 Conversion Software v2.20.0.422 (Illumina). The sequence quality was controlled by FastQC-0.10.1 [49]. Then, the reads were transformed to the fasta format using fastq_to_fasta (fastx-0.0.14, http://hannonlab.cshl.edu/fastx _ toolkit/) and a Phred score was assigned a Q score of 30 (Q30); reads were trimmed using fastx_clipper (fastx-0.0.14), and the unique reads were obtained using fastx_collapser (fastx-0.0.14). Datasets corresponding to the same treatment were merged into one file. The total number of known miRNAs was counted and annotated using the CLC Genomics Workbench 6.5.1 (CLC Bio, Aarhus, Denmark).

\section{7. miRNA Target Prediction and Functional Annotation}

The unique (non-redundant) 19 to $25 \mathrm{nt}$ sequences, across all six libraries representing the three treatments in two replicates, in total included the pool of five plants per treatment. Thus, 30 grapevine plants were used in this study. Datasets were submitted to the psRNATarget Analysis server (http://plantgrn.noble.org/psRNATarget/) to predict miRNAs [50]. The pssRNAMiner web server (http://bioinfo3.noble.org/pssRNAMiner/) [51] was used to identify both the clusters of phased small RNAs as well as the potential phase initiator. The CLC Genomics Workbench 6.5.1 (CLC Bio, Aarhus, Denmark) was used to calculate the abundance of unique miRNAs, and counting of the reads was done using UNIX custom scripts. The pipeline is outlined in Figure 1. 


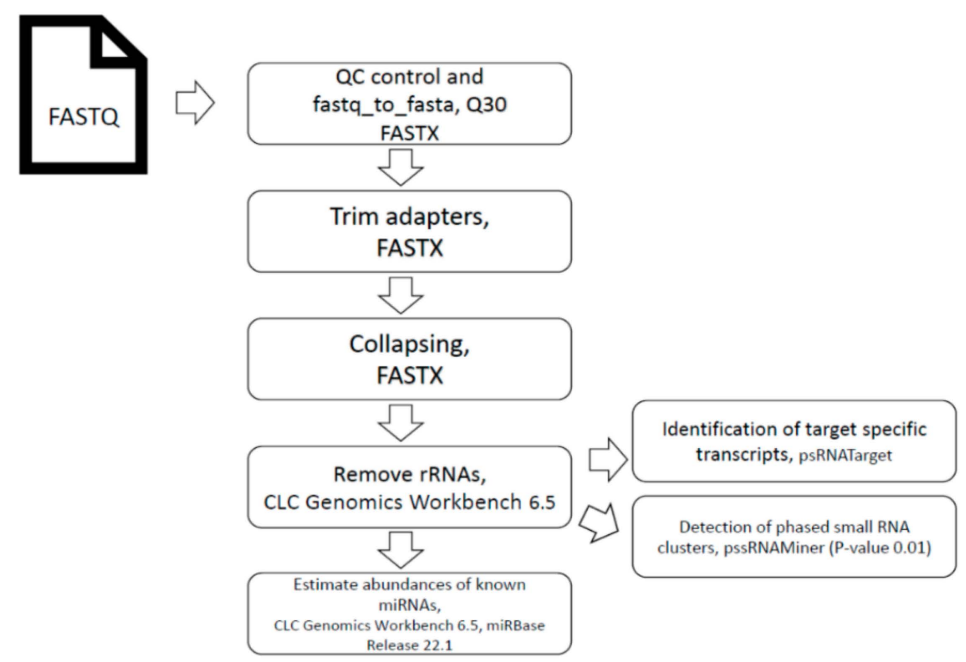

Figure 1. Flow chart of data processing.

\subsection{Validation of miRNA Expression Profiles by Real-Time RT-qPCR}

Small RNA sequencing on a MiniSeq system provided input data for the selection of sequences based on their different expression levels and prediction of fold-back structures. Stem-loop reverse transcription quantitative PCR (RT-qPCR) assays were performed according to the methods of Chen et al. [52] to validate the small RNA sequencing results. High-quality total RNA was prepared as described above. The total RNA of samples from each variant and replication were pooled equally according to the volume. Replications of each variant were then pooled according to the RNA weight. Finally, one pooled total RNA was prepared for each variant. For each miRNA, a $20-\mu \mathrm{L}$ reverse transcription reaction was prepared containing 100 U Superscript III reverse transcriptase (Invitrogen, Carlsbad, CA, USA), 20 U RiboLock RNase inhibitor (Thermo Scientific, Waltham, MA, United States), $1 \times$ first-strand buffer, $5 \mathrm{mM}$ DTT, $500 \mathrm{nM}$ dNTPs, $1 \mu \mathrm{M}$ miRNA-specific stem-loop RT primer, and $0.8 \mu \mathrm{g}$ pooled total RNA. Reverse transcription cycling conditions were as follows: $30 \mathrm{~min}$ at $16{ }^{\circ} \mathrm{C}, 60 \mathrm{~min}$ at $42{ }^{\circ} \mathrm{C}$, and heat inactivation for $10 \mathrm{~min}$ at $75^{\circ} \mathrm{C}$. qPCR was performed using the Universal ProbeLibrary (UPL) probe assay with UPL probe \#21 (Roche Diagnostics, Basel, Switzerland). Each $10 \mu \mathrm{L}$ of reaction mixture was prepared in triplicate and contained $1 \mu \mathrm{L}$ cDNA, $1 \times$ Colorless GoTaq Reaction Buffer (Promega, Madison, WI, USA), 2 mM MgCl 2 (Promega), 1 U GoTaq G2 DNA Polymerase (Promega), $0.5 \mu \mathrm{M}$ miRNA-specific forward primer, $0.5 \mu \mathrm{M}$ universal reverse primer, $0.2 \mu \mathrm{M}$ UPL probe, and nuclease-free water. The primer sequences are provided in Table S1. A control reaction, without a cDNA template, was included for each miRNA. Based on results from the geNorm analysis [53] (qBasePLUS v3.2, Biogazelle, Ghent, Belgium), miR166c was chosen as a reference to normalize miRNA expression levels. The Pfaffl method [54] was used for normalization to the reference miRNA. PCR amplification was performed in an ECO Real-Time PCR System (Illumina, San Diego, CA, USA), in which the baseline and threshold cycles $(\mathrm{Cq})$ were automatically determined with Eco Real-Time PCR System Software. Cycling conditions were as follows: $95^{\circ} \mathrm{C}$ for $2 \mathrm{~min}, 40$ cycles at $95^{\circ} \mathrm{C}$ for $15 \mathrm{~s}$, and $60^{\circ} \mathrm{C}$ for $1 \mathrm{~min}$. Relative miRNA expression analysis was performed using qBasePLUS v3.2 software (Biogazelle, Ghent, Belgium) [55].

\section{Results}

\subsection{Plant Inoculation}

Plants inoculated with $D$. eres did not show any symptoms on the first, third, and sixth day after inoculation (dai). However, small lesions on the leaves appeared on 10 dai (Figure 2). In contrast, plants inoculated with $D$. bohemiae showed visible symptoms on the leaves only 3 dai (Figure 2). Subsequently, 
brown necrosis occurred on the leaves within 6 dai. From the 10th day, more than half of the plants died. The control plants did not develop any symptoms (Figure 2).

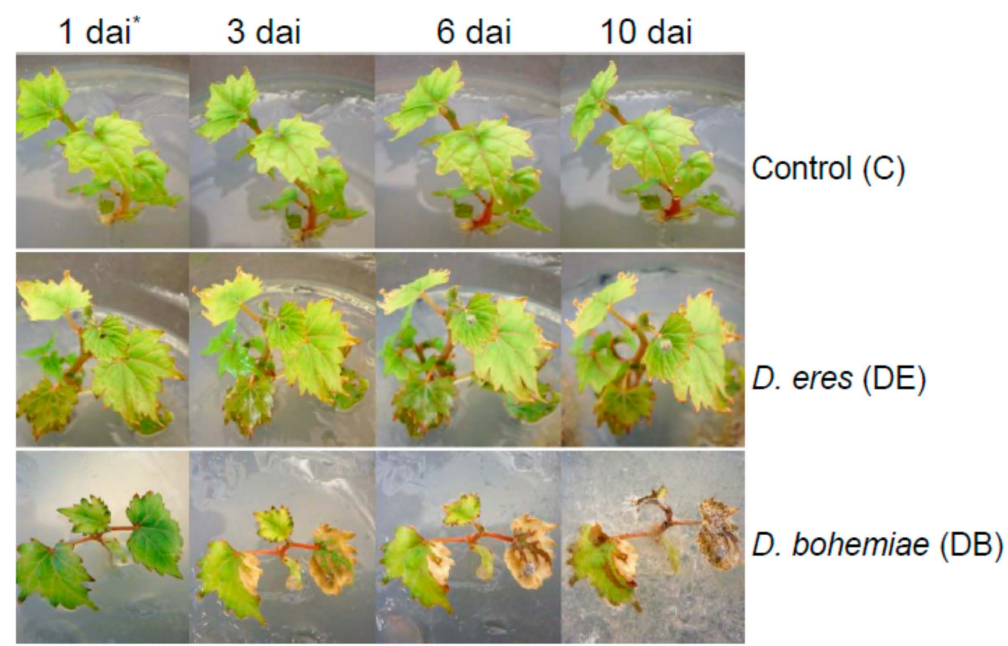

Figure 2. Treatments used in the study. * days after inoculation.

\subsection{The Abundance of sRNAs in Grapevines in Vitro}

In the present study, libraries representative of sRNA populations extracted from grapevine treatments DE, DB, and C, and sequenced by Illumina SBS technology, contained DE $=8.3 \times 10^{6}$, $\mathrm{DB}=5.8 \times 10^{6}$, and $\mathrm{C}=4.6 \times 10^{6}$ reads at $\mathrm{Q} 30$. After clipping, collapsing, and normalization per $10^{6}$ reads, $\mathrm{DE}, \mathrm{DB}$, and $\mathrm{C}$ contained $2,178,138 ; 3,399,118$; and 1,855,572 reads, respectively. The most abundant sRNAs were the 20- (DB) and 21-nt class (DE, C) (Figure 3). The lowest abundancy was recorded in 25-nt sRNAs through all the treatments. The most plant-decaying treatment, DB, had a similar 22- and 23-nt class profile as the DE treatment and C. A balanced sRNAs read distribution was recorded regarding the 22- and 23-nt sRNAs between all three treatments (Table 1).

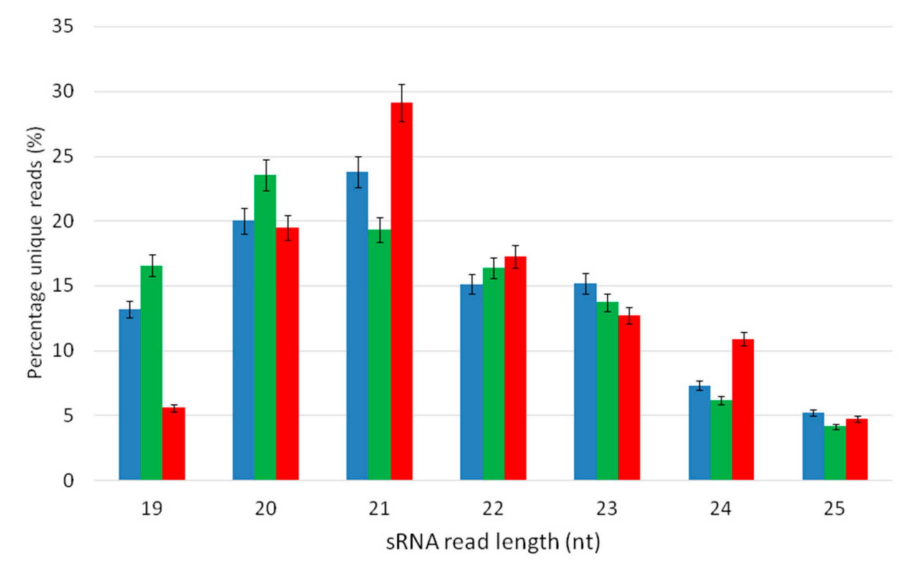

Figure 3. Bar plot depicting the size distribution of unique reads, psRNATarget. Blue-DE, green-DB, Red-C.

Table 1. Numbers of size distributions of unique reads normalized per 1,000,000.

\begin{tabular}{ccccccccc}
\hline & $\mathbf{1 9}$ & $\mathbf{2 0}$ & $\mathbf{2 1}$ & $\mathbf{2 2}$ & $\mathbf{2 3}$ & $\mathbf{2 4}$ & $\mathbf{2 5}$ & Total \\
\hline DE & 287,897 & 436,557 & 518,754 & 330,042 & 331,108 & 159,806 & 113,975 & $2,178,138$ \\
DB & 563,942 & 801,579 & 656,600 & 556,699 & 467,013 & 211,409 & 141,876 & $3,399,118$ \\
C & 104,300 & 362,066 & 540,728 & 320,848 & 236,014 & 202,736 & 88,881 & $1,855,572$ \\
\hline
\end{tabular}




\subsection{New and Conserved miRNAs Identified in Grapevine cv. Chardonnay in Vitro}

Sequence analysis coupled with the fold-back structure predictions for potential novel miRNAs led us to identify 41 new candidate miRNAs from grapevine (Table 2). Regarding the different expression levels, which are highlighted on the Figure 4, it is supposed that two miRNAs, 32 (CCCAGUCCCGAACCCGUCGG) and 41 (CCGGCGAUGCGCUCCUGGCC), are linked with the pathogenicity of DB. A gene encoding a Golgi protein [56] involved in several signaling events could be a putative target of miRNA 32. miRNA 41 is probably associated with the expression of RPP13-like protein 1 , a potential disease resistance protein. Representation of the newly identified miRNAs within the treatments is presented in Table S4.

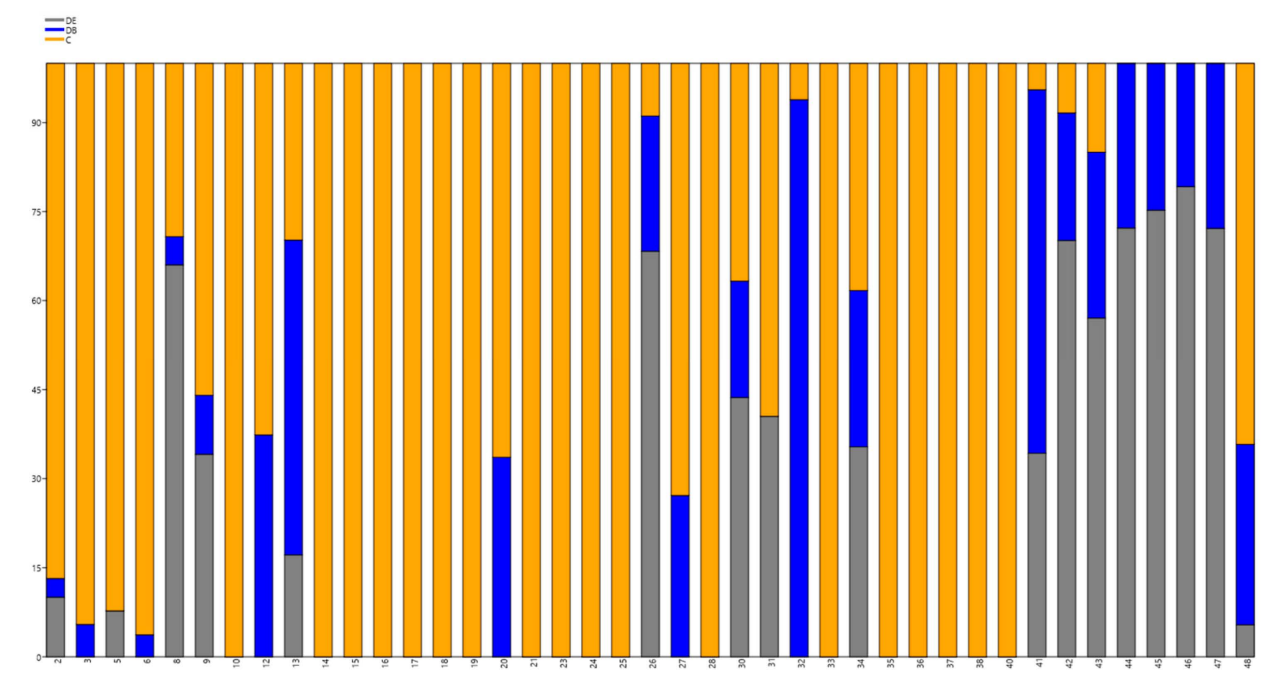

Figure 4. Stacked chart of normalized read counts per treatments DE, DB, and C. The plot was generated based on CLC Genomics Workbench normalized reads, generating novel small matured RNAs, and depicted using PAST version 3.25. The numbers on axis $\mathrm{X}$ correspond to Table 2, column miRNA name. Percentages are depicted on axis $\mathrm{Y}$.

A total of 136 conserved miRNAs were identified in grapevine cv. Chardonnay in vitro (Table S2). Among them, eight differentially expressed known grapevine miRNAs were revealed (Figure 5). Representation of the known miRNAs within the treatments is depicted in Figure 6, Table S3. The most abundant miRNAs were identified in the control, a more than $80 \%$ abundance in the case of Vvi-miR166c, Vvi-miR166a, Vvi-miR403a, and Vvi-miR156b,c,d. Distinctly, in the most affected DB treatment, Vvi-miR166a was the most abundant. 
Table 2. Putative miRNAs identified using CLC Genomics WB 6.5.1, putative targets determined by blastN/NCBI and by psRNATarget with the possible type of inhibition.

\begin{tabular}{|c|c|c|c|c|}
\hline miRNA Name & miRNA Sequence & Putative Target Identified Using NCBI & $\begin{array}{l}\text { Target Acc. Based on the Highest Expectations } \\
\text { (E), psRNA Target }\end{array}$ & Inhibition \\
\hline 2 & CCCAGUCCCGAACCCGUCGGC & $\begin{array}{l}\text { similar to aspartate aminotransferase; similar to } \\
\text { Aspartate aminotransferase 2, transcript variant } \\
\text { X9, misc_RNA, importin } \alpha \text { isoform } 9\end{array}$ & chr11.gff3_MRNA_VIT_11s0149g00200.t01 & Cleavage \\
\hline 3 & AGUUACUAAUUCAUGAUCUGGC & importin $\alpha$ isoform 9 & chr2.gff3_MRNA_VIT_02s0033g00980.t01 & Cleavage \\
\hline 5 & CCAGUCCCGAACCCGUCGGC & $\begin{array}{l}\text { Vitis vinifera contig VV78X128415.10, whole } \\
\text { genome shotgun sequence }\end{array}$ & chr7_random.gff3_MRNA_VIT_07s0151g00980.t01 & Cleavage \\
\hline 6 & UCUCGGACCAGGCUUCAUUCC & $\begin{array}{l}\text { Vitis vinifera microRNA MIR166a (MIR166A), } \\
\text { microRNA, http://www.mirbase.org/cgi-bin/ } \\
\text { mature.pl?mature_acc=MIMAT0020658 }\end{array}$ & chr18.gff3_MRNA_VIT_18s0075g00480.t01 & Translocation \\
\hline 8 & GGUGGCUGUAGUUUAGUGGU & $\begin{array}{l}\text { Vitis vinifera contig VV78X038801.3, whole } \\
\text { genome shotgun sequence }\end{array}$ & chr18.gff3_MRNA_VIT_18s0001g12770.t01 & Cleavage \\
\hline 9 & CGGUGGACUGCUCGAGCUGC & $\begin{array}{l}\text { Vitis vinifera contig VV78X196950.19, whole } \\
\text { genome shotgun sequence }\end{array}$ & chr15.gff3_MRNA_VIT_15s0048g02810.t01 & Translocation \\
\hline 10 & CUAACAGACCGGUAGACUUGAAC & $\begin{array}{l}\text { Vitis vinifera contig VV78X130314.7, whole } \\
\text { genome shotgun sequence }\end{array}$ & chr15.gff3_MRNA_VIT_15s0048g02810.t01 & Translation \\
\hline 12 & CCCAGUCCCGAACCCGUCGGCU & $\begin{array}{l}\text { Vitis vinifera contig VV78X156561.10, whole } \\
\text { genome shotgun sequence }\end{array}$ & chr11.gff3_MRNA_VIT_11s0149g00200.t01 & Cleavage \\
\hline 13 & GCGCCUGUAGCUCAGUGGA & $\begin{array}{l}\text { Vitis vinifera contig VV78X046944.3, whole } \\
\text { genome shotgun sequence }\end{array}$ & chr8.gff3_MRNA_VIT_08s0007g07620.t01 & Cleavage \\
\hline 14 & UUCAUGGACGUUGAUAAGAUCCU & $\begin{array}{l}\text { Vitis vinifera subsp. sylvestris chloroplast DNA, } \\
\text { complete genome }\end{array}$ & chr7.gff3_MRNA_VIT_07s0005g00750.t01 & Cleavage \\
\hline 15 & UAACAGACCGGUAGACUUGAAC & $\begin{array}{l}\text { PREDICTED: Vitis vinifera pentatricopeptide } \\
\text { repeat-containing protein At5g50990 } \\
\text { (LOC100247459) }\end{array}$ & chr18.gff3_MRNA_VIT_18s0001g09480.t01 & Cleavage \\
\hline 16 & UGCACUGCCUCUUCCCUGGCU & $\begin{array}{l}\text { Vitis vinifera microRNA MIR408 gene, complete } \\
\text { sequence, http://www.mirbase.org/cgi-bin/mirna_ } \\
\text { entry.pl?acc=MI0005917 }\end{array}$ & chr18.gff3_MRNA_VIT_18s0001g15240.t01 & Cleavage \\
\hline 17 & CCUAACAGACCGGUAGACUUGAAC & $\begin{array}{l}\text { PREDICTED: Vitis vinifera ATP synthase subunit } \\
\alpha \text {, chloroplastic-like (LOC109124299), mRNA }\end{array}$ & chr18.gff3_MRNA_VIT_18s0001g11300.t01 & Cleavage \\
\hline 18 & UCCUAACAGACCGGUAGACUUGAAC & $\begin{array}{l}\text { Vitis vinifera subsp. sylvestris chloroplast DNA, } \\
\text { complete genome }\end{array}$ & chr18.gff3_MRNA_VIT_18s0001g11300.t01 & Cleavage \\
\hline
\end{tabular}


Table 2. Cont

\begin{tabular}{|c|c|c|c|c|}
\hline miRNA Name & miRNA Sequence & Putative Target Identified Using NCBI & $\begin{array}{l}\text { Target Acc. Based on the Highest Expectations } \\
\text { (E), psRNA Target }\end{array}$ & Inhibition \\
\hline 19 & UCCUAACAGACCGGUAGACUUGAAC & $\begin{array}{l}\text { Vitis vinifera subsp. sylvestris chloroplast DNA, } \\
\text { complete genome }\end{array}$ & chr18.gff3_MRNA_VIT_18s0001g11300.t01 & Cleavage \\
\hline 20 & UUAGAUGAUCAUCAACAAACU & $\begin{array}{l}\text { Vitis vinifera ankyrin repeat-containing protein } \\
\text { NPR4-like (LOC100260982), transcript variant X10, } \\
\text { mRNA }\end{array}$ & chr7.gff3_MRNA_VIT_07s0005g02430.t01 & Cleavage \\
\hline 21 & CAGACCGGUAGACUUGAAC & $\begin{array}{l}\text { PREDICTED: Vitis vinifera ATP synthase subunit } \\
\alpha \text {, chloroplastic-like (LOC109124299), mRNA }\end{array}$ & chr19.gff3_MRNA_VIT_19s0090g01480.t01 & Cleavage \\
\hline 23 & ACAGACCGGUAGACUUGAAC & $\begin{array}{l}\text { PREDICTED: Vitis vinifera ATP synthase subunit } \\
\alpha \text {, chloroplastic-like (LOC109124299), mRNA }\end{array}$ & chr18.gff3_MRNA_VIT_18s0001g09480.t01 & Cleavage \\
\hline 24 & UUCCACAGCUUUCUUGAACUU & $\begin{array}{l}\text { Vitis vinifera microRNA MIR396b (MIR396B), } \\
\text { microRNA }\end{array}$ & chr15.gff3_MRNA_VIT_15s0021g02580.t01 & Cleavage \\
\hline 25 & AACAGACCGGUAGACUUGAAC & $\begin{array}{l}\text { PREDICTED: Vitis vinifera ATP synthase subunit } \\
\alpha \text {, chloroplastic-like (LOC109124299), mRNA }\end{array}$ & chr18.gff3_MRNA_VIT_18s0001g09480.t01 & Cleavage \\
\hline 26 & CCGGCGAUGCGCUCCUGGCC & $\begin{array}{l}\text { Vitis vinifera contig VV78X197078.6, whole } \\
\text { genome shotgun sequence }\end{array}$ & chr12.gff3_MRNA_VIT_12s0034g02480.t01 & Cleavage \\
\hline 27 & CAGUCCCGAACCCGUCGGC & $\begin{array}{l}\text { Vitis vinifera contig VV78X156561.10, whole } \\
\text { genome shotgun sequence }\end{array}$ & chr11.gff3_MRNA_VIT_11s0149g00200.t01 & Cleavage \\
\hline 28 & UGUUGAGCUCACCUUGUACCC & $\begin{array}{l}\text { PREDICTED: Vitis vinifera kinase-interacting } \\
\text { family protein (LOC100246194), transcript variant } \\
\text { X1, mRNA }\end{array}$ & chr9.gff3_MRNA_VIT_09s0002g03120.t01 & Translation \\
\hline 30 & CGGUGGACUGCUCGAGCUGCU & $\begin{array}{l}\text { Vitis vinifera contig VV78X156561.10, whole } \\
\text { genome shotgun sequence }\end{array}$ & chr15.gff3_MRNA_VIT_15s0048g02810.t01 & Translation \\
\hline 31 & GUUGAGCUCACCUUGUACCCA & $\begin{array}{l}\text { PREDICTED: Vitis vinifera kinase-interacting } \\
\text { family protein (LOC100246194), transcript variant } \\
\text { X1, mRNA }\end{array}$ & chr9.gff3_MRNA_VIT_09s0002g03120.t01 & Translation \\
\hline 32 & CCCAGUCCCGAACCCGUCGG & $\begin{array}{l}\text { Vitis vinifera contig VV78X128415.10, whole } \\
\text { genome shotgun sequence, mRNA sequence acyl } \\
\text { CoA binding protein domain containing protein } 3 \\
\text { which is a Golgi protein involved in several } \\
\text { signalling events }\end{array}$ & chr6.gff3_MRNA_VIT_06s0004g04740.t01 & Cleavage \\
\hline 33 & UGAAGGUCCAAGGCCGAGGCU & $\begin{array}{l}\text { PREDICTED: Vitis vinifera uncharacterized } \\
\text { LOC100855078 (LOC100855078), ncRNA }\end{array}$ & chr14.gff3_MRNA_VIT_14s0006g03100.t01 & Cleavage \\
\hline
\end{tabular}


Table 2. Cont

\begin{tabular}{|c|c|c|c|c|}
\hline miRNA Name & miRNA Sequence & Putative Target Identified Using NCBI & $\begin{array}{l}\text { Target Acc. Based on the Highest Expectations } \\
\text { (E), psRNA Target }\end{array}$ & Inhibition \\
\hline 34 & GGGAUGGGUCGACCGGUCC & $\begin{array}{l}\text { Vitis vinifera contig VV78X071755.8, whole } \\
\text { genome shotgun sequence }\end{array}$ & chr12.gff3_MRNA_VIT_12s0034g01520.t01 & Cleavage \\
\hline 35 & UCGGAUAAAGGGUUAUACAUC & $\begin{array}{l}\text { PREDICTED: Vitis vinifera uncharacterized } \\
\text { LOC100853315 (LOC100853315), transcript variant } \\
\text { X1, ncRNA }\end{array}$ & chr6.gff3_MRNA_VIT_06s0009g03800.t01 & Cleavage \\
\hline 36 & UGCACUGCCUCUUCCCUGGC & $\begin{array}{l}\text { Vitis vinifera microRNA MIR408 (MIR408), } \\
\text { microRNA }\end{array}$ & chr18.gff3_MRNA_VIT_18s0001g15240.t01 & Cleavage \\
\hline 37 & CUGGAUUAUGACUGAACGCCU & $\begin{array}{l}\text { PREDICTED: Vitis vinifera lysosomal Pro-X } \\
\text { carboxypeptidase (LOC100244772), transcript } \\
\text { variant X2, mRNA }\end{array}$ & chr4.gff3_MRNA_VIT_04s0210g00160.t01 & Cleavage \\
\hline 38 & UUCCACAGCUUUCUUGAACU & $\begin{array}{l}\text { Vitis vinifera microRNA MIR396c (MIR396C), } \\
\text { microRNA }\end{array}$ & chr15.gff3_MRNA_VIT_15s0021g02580.t01 & Cleavage \\
\hline 40 & AGUUACUAAUUCAUGAUCUGGCC & $\begin{array}{l}\text { PREDICTED: Vitis vinifera scopoletin } \\
\text { glucosyltransferase (LOC100260498), mRNA }\end{array}$ & chr2.gff3_MRNA_VIT_02s0033g00980.t01 & Cleavage \\
\hline 41 & CCGGCGAUGCGCUCCUGGCC & $\begin{array}{l}\text { mRNA sequence with expression of RPP13-like } \\
\text { protein 1, potential disease resistance protein }\end{array}$ & chr12.gff3_MRNA_VIT_12s0034g02480.t01 & Cleavage \\
\hline 42 & CCGGCGAUGCGCUCCUGGCCU & $\begin{array}{l}\text { PREDICTED: Vitis vinifera putative disease } \\
\text { resistance RPP13-like protein } 1 \text { (LOC100258269), } \\
\text { transcript variant X4, mRNA }\end{array}$ & chr12.gff3_MRNA_VIT_12s0034g02480.t01 & Cleavage \\
\hline 43 & ACCGGCGAUGCGCUCCUGGCCU & $\begin{array}{l}\text { PREDICTED: Vitis vinifera auxin efflux carrier } \\
\text { component } 3 \text { (LOC100268124), mRNA }\end{array}$ & chr1.gff3_MRNA_VIT_01s0011g01820.t01 & Cleavage \\
\hline 44 & GCCCGUGGAGACGUCGUCGCCUCG & $\begin{array}{l}\text { PREDICTED: Vitis vinifera oxalate-CoA ligase } \\
\text { (LOC100256632), mRNA }\end{array}$ & chr1.gff3_MRNA_VIT_01s0011g00770.t01 & Cleavage \\
\hline 45 & CGCCGUCCGAAUUGUAGUCUGGA & $\begin{array}{l}\text { PREDICTED: Vitis vinifera uncharacterized } \\
\text { LOC109123385 (LOC109123385), mRNA }\end{array}$ & chr12.gff3_MRNA_VIT_12s0134g00450.t01 & Cleavage \\
\hline 46 & UCGGGUUAACAUUCCUGAACCGGGA & $\begin{array}{l}\text { PREDICTED: Vitis vinifera AUGMIN subunit } 7 \\
\text { (LOC100243653), transcript variant X1, mRNA }\end{array}$ & chr1.gff3_MRNA_VIT_01s0011g01130.t01 & Cleavage \\
\hline 47 & CGGUGGACUGCUCGAGCUGCU & $\begin{array}{l}\text { PREDICTED: Vitis vinifera non-specific } \\
\text { lipid-transfer protein-like protein At5g64080 } \\
\text { (LOC100247017), mRNA }\end{array}$ & chr15.gff3_MRNA_VIT_15s0048g02810.t01 & Translation \\
\hline 48 & CCAGUCCCGAACCCGUCGGC & $\begin{array}{l}\text { PREDICTED: Vitis vinifera acyl-CoA-binding } \\
\text { domain-containing protein } 3 \text { (LOC100268114), } \\
\text { transcript variant X6, mRNA }\end{array}$ & chr7_random.gff3_MRNA_VIT_07s0151g00980.t01 & Cleavage \\
\hline
\end{tabular}




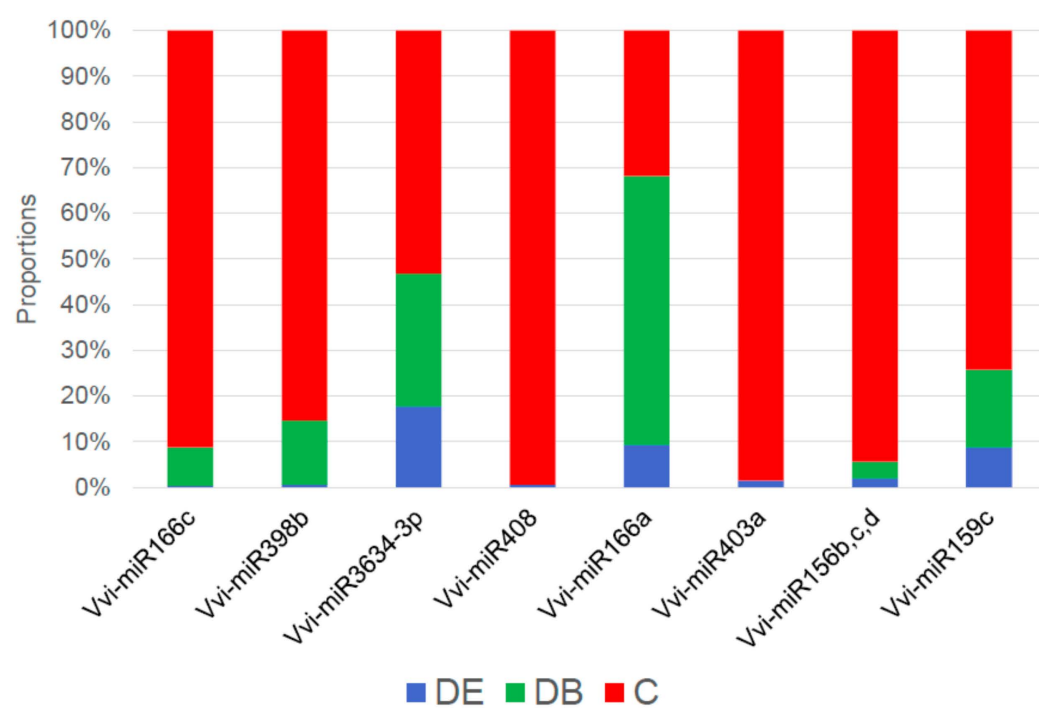

Figure 5. Bar plot depicting the proportions of treatments across known detected grapevine matured miRNAs, CLC Genomics Workbench, miRBase Release 22.1. Proportions were calculated based on normalized total reads.

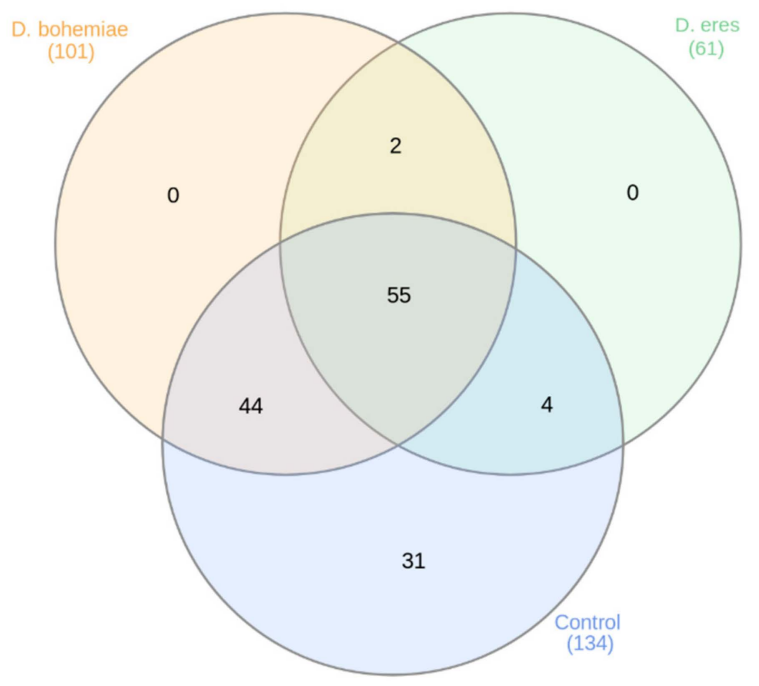

Figure 6. Venn diagram showing the representation of 136 known miRNAs.

\section{4. miRNA Expression Profiles by Real-Time RT-qPCR}

Real-time RT-qPCR revealed the expression profiles of nine miRNAs, two novel and seven known, for grapevine (Figure S1). Both novel miRNAs, 32 and 41, were overexpressed in DB-inoculated plants and less expressed in DE and C. Their overexpression in DB was confirmed by RT-qPCR, while it also revealed a higher expression of miRNA 32 and 41 in the $C$ than the DE treatment, which was not observed in the small RNA sequencing results (Figure 4).

Known grapevine miRNAs Vvi-miR156b,c,d, Vvi-miR166a, Vvi-miR166c, Vvi-miR3634-3p, Vvi-miR398b, Vvi-miR403a, and Vvi-miR408 were also quantified by RT-qPCR. Both miRNAs of the 166 family were highly expressed in all treatments, with a higher abundance in C and DB, as compared to DE. A high overexpression in C was revealed for miRNAs Vvi-miR156b,c,d and Vvi-miR398b, in agreement with the small RNA sequencing results. The RT-qPCR results also revealed an overexpression of miRNA Vvi-miR408 in DB, but according to small RNA sequencing, it was upregulated in C (Figures 4 and 5). Similarly, Vvi-miR403a, which was most abundant in DE according to RT-qPCR, showed over a 90\% abundance in C as revealed by small RNA sequencing. Vvi-miR166c 
and Vvi-miR3634-3p showed a relatively similar expression in all treatments in small RNA sequencing, which was further confirmed by RT-qPCR.

\section{Discussion}

This is the first attempt to use small RNA high-throughput sequencing data to identify miRNAs differentially expressed in $V$. vinifera $\mathrm{cv}$. Chardonnay in response to $D$. eres and $D$. bohemiae isolated from grapevine in the Czech Republic. The experimental strategy applied in this study was designed to investigate the profile of grapevine miRNAs in response to fungal infection in vitro because there are no unpredictable abiotic factors. Plant-pathogen interactions were entirely dissociated from the environment, which is usually used in the sRNAs profiling of stressed plants [57,58]. Ma et al. [58] also found that the fungal sRNA enrichment was lower in planta than during in vitro growth. In this study, we used the cultivar Chardonnay since it is a popular grapevine cultivar all around the world [59], and in previous research, it showed a high level of tolerance against natural infections of GTD pathogens in Italy $[60,61]$.

In this study, we revealed that the most abundant sRNAs were the 20- (DB) and 21-nt class (DE, C), corresponding with the results of Pantaleo et al. [45]. Previous studies showed that 24-nt sRNAs were more abundant in plants than the 21-nt class [62-64]. This is possibly because of the concerted activity of plant-specific DNA-dependent RNA polymerases, PolIVa and PolIVb, with the accumulation of 24-nt heterochromatic siRNAs via RDR2-mediated dsRNA formation and DCL3-mediated processing $[65,66]$. Many known grapevine miRNAs [45] were found in our datasets from whole grapevine plants cultivated in vitro (Table S2). In addition, 41 novel miRNA candidates were identified. In general, the selected miRNA profiles measured by qRT-PCR confirmed the sequencing data. A few discrepancies observed were within the range of those reported by Pantaleo et al. [67]. Similar inconsistencies were also previously reported for some miRNAs when high-throughput sequencing and northern blot analyses were compared, for example, for miR3633 and some other conserved and grapevine-specific miRNAs [45]. Small RNA high-throughput sequencing is reported to produce bias. Further, the use of different adapters and barcodes during ligation as well as complex RNA structures and modifications affect cDNA synthesis efficacies and exemplify sources of bias in deep sequencing [68]. We also observed some discrepancies in the detection of novel miRNA candidates, miRNA names 6 [69], 16 [70], 24, 36, and 38 [43] in Table 2, suggesting that these miRNAs are already known.

The miRNA candidates 32 and 41 have not been previously reported. We were able to amplify them by RT-qPCR, thus identifying their targets. For the miRNA 32 targets chr6.gff3_MRNA_VIT_06s0004g04740.t01 (Except 3.0, Inhibition-Cleavage), we found that it targets the mRNA sequence acyl-CoA-binding protein domain containing protein 3, which is a Golgi protein involved in several signaling events [56]. This could be linked with the higher in vitro virulence of $D$. bohemiae compared to $D$. eres. Golgi body-mediated signaling is linked to its fragmentation and regeneration during the mitotic cycle of the cell. During this process, Golgi-resident proteins are released to the cytosol and interact with other signaling molecules to regulate various cellular processes. Acyl-coenzyme A binding domain containing 3 protein (ACBD3) is a Golgi protein involved in several signaling events. ACBD3 protein was previously known as a peripheral-type benzodiazepine receptor and cAMP-dependent protein kinase associated protein 7 (PAP7), Golgi complex-associated protein of $60 \mathrm{kDa}$ (GCP60), Golgi complex-associated protein 1 (GOCAP1), and Golgi phosphoprotein 1 (GOLPH1) [56]. If the regeneration process during the mitotic cycle of the cell is influenced by an abundancy of miRNA 32, it would be associated with a higher virulence of $D$. bohemiae.

Regarding miRNA 41 targets chr12.gff3_MRNA_VIT_12s0034g02480.t01 (Except 3.0, Inhibition-Cleavage), the miRNA 41 is focused on the mRNA sequence with an expression of RPP13-like protein 1, which is potentially a disease resistance protein. This phenomenon was described by [71], proving that RPP13 is a simple locus in Arabidopsis thaliana for alleles that specify downy mildew resistance to different avirulence determinants in Peronospora parasitica. It could be the case in our study that the miRNA 41 regulates the pathogenicity of the fungus Diaporthe on the grapevines 
in vitro. It could be the case that miRNA 41 and RPP13 are elements of the resistance mechanism [71], as RPP13 are well-known plant R genes governing hypersensitivity (HR)-based resistance [72], which may result in the phenotypic effect observed upon massive inoculation by DB in vitro, while the pathogen is effectively eliminated by grapevine in regular (field) conditions.

The results suggest some hypothetical interactions between miRNAs and the physiological changes induced in grapevine by Diaporthe in vitro (miR3634, miR408, miR403) similar to those described by Pantaleo et al. [67] that linked miRNAs, physiological changes, and Grapevine rupestris stem-pitting associated virus infection with miR156, miR164, miR319, miR394, and miR396.

Vvi-miR166c and Vvi-miR166a are thought to target mRNA coding for HD-Zip transcription factors, including Phabulosa (PHB) and Phavoluta (PHV), that regulate axillary meristem initiation and leaf development [73]. MicroRNAs 165 and 166 are able to cleave their target mRNAs of HD-ZIP III genes, thus regulating the functions of these genes [74]. Du et al. [75] indicated that class III homeodomain leucine zipper transcription factors (HD-ZIP III TFs) and microRNA 165/166 (miR165/166) may play important roles in secondary cell wall formation. The HD-ZIP III TFs regulate a number of developmental processes, such as embryo patterning, meristem initiation and homeostasis, lateral organ polarity, and vascular development, in Arabidopsis [76].

The miR166 overexpresssors exhibit an enlargement of the shoot apical meristem (SAM) and an enhancement of vascular development of Arabidopsis [77]. The expression level of miRNAs 166 was not linked with Diaporthe infection on grapevines in this study. Based on HTS analysis, Vvi-miR166c was mostly expressed in the $C$ treatment, which corresponds to previously published research by Jung et al. [78]. This finding indicated that SAM machinery works properly in a balanced expression of miR165 and miR166; however, no differences between treatments were found by RT-qPCR [78].

In our study, the analyses of miR166a did not show clear conclusions. According to RT-qPCR, the lowest expression level was in DE and was almost similar in DB and C. On the other hand, Kim et al. [79] reported that the men 1 mutant of Arabidopsis overexpressing the MIR166a gene exhibited pleiotropic phenotypes, such as stunted growth, disrupted floral structure, fasciated inflorescence stem, and enlarged SAM. Our HTS analysis showed the lowest expression level in DE and the highest in DB.

We analyzed these miR398 mostly overexpressed miRNAs in C by both methods. The Vvi-miR398b sequence belongs to the miR398 family of miRNAs, which are predicted to target mRNAs coding for copper superoxide dismutases an cytochrome $\mathrm{C}$ oxidase subunit $\mathrm{V}$ [80].

Our study provided data that described a similar representation of Vvi-miR3634-3p in DE, DB, and C. Chitarra et al. [81] reported a similar representation of Vvi-miR3634-3p. Vvi-miR3634-3p were identified by [45] as being up-regulated in Grapevine rupestris stem-pitting associated virus-infected grapevines. Vvi-miR3634-3p were also the most expressed in "Barbera" grapevine leaf midribs that were infected with Flavescence dorée [81].

Mica et al. [46] indicated that miRNAs Vvi-miR408 were extremely highly expressed in root tissues, targeting various copper proteins: Plantacyanin, laccases, and a superoxide dismutase, all putatively involved in stress responses and lignification. These miRNAs have also been shown to be coexpressed in Arabidopsis under conditions of copper deprivation [82]. Our results agree with their findings because the in vitro media had low contents of copper. Diaporthe infection probably influenced the Vvi-miR408 expression. HTS revealed that Diaporthe-infected grapevines were Vvi-miR408 downregulated but RT-qPCR showed the highest expression of these miRNAs in DB, thus there could also be a link with the biotic stress caused by fungal infection.

Vvi-miR403a encodes a miRNA that targets AGO2 and AGO3 [83]. Regarding the results of this study, Vvi-miR403a were mostly expressed in the control treatment according to HTS, but DE showed the highest expression of Vvi-miR403a according to RT-qPCR. Vvi-miR156b,c,d are predicted to target mRNAs coding for squamosa-promoter binding protein (SBP)-like transcription factors and our HTS and RT-qPCR results confirmed the highest expression in C. These genes encode a family of plant-specific transcription factors that play vital roles in plant growth and development [84]. 
Vvi-miR159c is usual plant miRNA and is thought to target mRNAs coding for MYB proteins that are known to bind to the promoter of the floral meristem identity gene LEAFY [73]. Flowering plants produce floral meristems in response to intrinsic and extrinsic flowering inductive signals [85]. According to our results, these miRNAs were also mostly expressed in the $C$ treatment.

In general, $D$. bohemiae was more pathogenic to grapevine than $D$. eres, unlike the results of Guarnaccia et al. [4]. This can be explained by the fact that Guarnaccia et al. [4] used a different inoculation method for Diaporthe $[19,27]$, using green shoots cut from healthy mature grapevine cv. Riesling, and the shoots were artificially inoculated with a 1-week-old 6-mm agar plug to determine the pathogenicity. Here, we used a 1-week-old 3-mm plug for the inoculation of a single leave of grapevine cv. Chardonnay in vitro; this was repeated two times, and the pathogenicity to the grapevine was confirmed in vitro. Additionally, the life cycle of Diaporthe on grapevines starts on green parts and more intensively on the leaves [86]. The pathogenicity of D. bohemiae CBS 143347 should be further studied with different methods of inoculation.

\section{Conclusions}

The outcomes of this study provide novel insights into D. eres and D. bohemiae pathogenicity and the $V$. vinifera $\mathrm{cv}$. Chardonnay defense mechanism in vitro. The results revealed that $D$. eres has the ability to be phytopathogenic and that it triggers some specific miRNAs expression. Surprisingly, $D$. bohemiae was previously published as non-phytopathogenic fungus, but in our study, it was found to be more virulent than $D$. eres. In addition, some selected miRNAs were expressed more in $D$. bohemiae than in both the $D$. eres and control treatments. We also identified two novel miRNAs, named 32 and 41 , which appear to be linked with the pathogenicity of $D$. bohemiae in vitro. Further studies focusing on the mechanism of RNA silencing, used as a strategy against grapevine trunk disease pathogens, are necessary to understand the mechanism of fast, strong, and effective defense responses to grapevine trunk fungal pathogens.

Supplementary Materials: The following are available online at http://www.mdpi.com/2073-4425/10/11/905/s1. Figure S1: Relative quantification based on stem-loop RT-qPCR of differently expressed miRNAs in different variants. miRNA Vvi-miR 166c is the reference miRNA and the bars represent fold expressions compared to the reference miRNA. DE is the Diaporthe eres treated, DB is Diaporthe bohemiae treated and C is control. Relative miRNA quantification was analysed in qBasePLUS v3.2 software (Biogazelle, Ghent, Belgium), Table S1: List of primer sequences used in the real-time RT-qPCR assay for relative quantification of target miRNAs. Table S2: Identification of total known grapevine miRNAs. Data were generated by CLC Genomics WB 6.5.1, the reads were analyzed using extraction and counting of the reads. Annotation and merging of the counts were used. Table S3: Representation of known miRNAs in the treatments DE, DB and C. Table S4: Representation of new miRNAs in the treatments DE, DB and C.

Author Contributions: The study was conceived by A.E., D.G. (David Gramaje) and D.G. (Dariusz Grzebelus). All authors contributed to the data collection. Data interpretation and manuscript preparation were performed by A.E., E.P., J.P. and M.B., A.E., R.P., A.B.-T., J.C., E.P. and T.K. performed the experiments. A.E., D.G. (David Gramaje), D.G. (Dariusz Grzebelus) and T.K. contributed to bioinformatics data analysis. All authors critically reviewed and edited the manuscript and approved its publication.

Funding: This work was supported from ERDF "Multidisciplinary research to increase application potential of nanomaterials in agricultural practice" (No. CZ.02.1.01/0.0/0.0/16_025/0007314). This research was also supported by the project No. TJ02000096.

Acknowledgments: The authors thank Eva Ondrusikova and Jana Moudra (MENDELU, Mendeleum-Dept. of Genetics) for the support in in vitro cultivation.

Conflicts of Interest: The authors declare that the research was conducted in the absence of any commercial or financial relationships that could be construed as a potential conflict of interest. 


\section{References}

1. Muralli, T.S.; Suryanarayanan, T.S.; Geeta, R. Endophytic Phomopsis species: Host range and implications for diversity estimates. Can. J. Microbiol. 2006, 52, 673-680. [CrossRef] [PubMed]

2. Garcia-Reyne, A.; López-Medrano, F.; Morales, J.M.; García Esteban, C.; Martín, I.; Eraña, I.; Meije, Y.; Lalueza, A.; Alastruey-Izquierdo, A.; Rodríguez-Tudela, J.L.; et al. Cutaneous infection by Phomopsis longicolla in a renal transplant recipient from Guinea: First report of human infection by this fungus. Transpl. Infect. Dis. 2011, 13, 204-207. [CrossRef] [PubMed]

3. Santos, J.M.; Vrandecčicć, K.; CĆosicć, J.; Duvnjak, T.; Phillips, A. Resolving the Diaporthe species occurring on soybean in Croatia. Persoonia 2011, 27, 9-19. [CrossRef] [PubMed]

4. Guarnaccia, V.; Groenewald, J.Z.; Woodhall, J.; Armengol, J.; Cinelli, T.; Eichmeier, A.; Ezra, D.; Fontaine, F.; Gramaje, D.; Gutierrez-Aguirregabiria, A.; et al. Diaporthe diversity and pathogenicity revealed from a broad survey of grapevine diseases in Europe. Pers. Mol. Phylogeny Evol. Fungi 2018, 40, 135-153. [CrossRef] [PubMed]

5. Gramaje, D.; Úrbez-Torres, J.R.; Sosnowski, M.R. Managing grapevine trunk diseases with respect to etiology and epidemiology: Current strategies and future prospects. Plant Dis. 2018, 102, 12-39. [CrossRef]

6. Van Rensburg, J.C.J.; Lamprecht, S.C.; Groenewald, J.Z.; Castlebury, L.A.; Crous, P.W.; Van Rensburg, J.C.J. Characterization of Phomopsis spp. associated with die-back of rooibos (Aspalathus linearis) in South Africa. Stud. Mycol. 2006, 55, 65-74. [CrossRef] [PubMed]

7. Santos, J.M.; Phillips, A.J.L. Resolving the complex of Diaporthe (Phomopsis) species occurring on Foeniculum vulgare in Portugal. Fungal Divers. 2009, 34, 111-125.

8. Crous, P.; Groenewald, J.; Shivas, R.; Edwards, J.; Seifert, K.; Alfenas, A.; Alfenas, R.; Burgess, T.; Carnegie, A.; Hardy, G.; et al. Fungal Planet description sheets: 69-91. Persoonia 2011, 26, 108-156. [CrossRef]

9. Crous, P.W.; Summerell, B.A.; Swart, L.; Denman, S.; Taylor, J.E.; Bezuidenhout, C.M.; Palm, M.E.; Marincowitz, S.; Groenewald, J.Z. Fungal pathogens of Proteaceae. Persoonia 2011, 27, 20-45. [CrossRef]

10. Thompson, S.; Tan, Y.; Young, A.; Neate, S.; Aitken, E.; Shivas, R. Stem cankers on sunflower (Helianthus annuus) in Australia reveal a complex of pathogenic Diaporthe (Phomopsis) species. Persoonia 2011, 27, 80-89. [CrossRef]

11. Gramaje, D.; Agustí-Brisach, C.; Pérez-Sierra, A.; Moralejo, E.; Olmo, D.; Mostert, L.; Damm, U.; Armengol, J. Fungal trunk pathogens associated with wood decay of almond trees on Mallorca (Spain). Pers. Mol. Phylogeny Evol. Fungi 2012, 28, 1. [CrossRef] [PubMed]

12. Grasso, F.M.; Marini, M.; Vitale, A.; Firrao, G.; Granata, G. Canker and dieback on Platanus $\times$ acerifolia caused by Diaporthe scabra. For. Pathol. 2012, 42, 510-513. [CrossRef]

13. Huang, F.; Hou, X.; Dewdney, M.M.; Fu, Y.; Chen, G.; Hyde, K.D.; Li, H. Diaporthe species occurring on citrus in China. Fungal Diversity 2013, 61, 237-250. [CrossRef]

14. Lombard, L.; Van Leeuwen, G.C.M.; Guarnaccia, V.; Polizzi, Z.; Rijswick, P.C.J.V.; Rosendahl, K.C.H.M.V.; Gabler, J.; Crous, P.W. Diaporthe species associated with Vaccinium, with specific reference to Europe. Phytopathol. Mediterr. 2014, 53, 287-299. [CrossRef]

15. Gao, Y.H.; Liu, F.; Cai, L. Unravelling Diaporthe species associated with Camellia. Syst. Biodivers. 2016, 14, 102-117. [CrossRef]

16. Udayanga, D.; Castlebury, L.A.; Rossman, A.Y.; Chukeatirote, E.; Hyde, K.D. The Diaporthe sojae species complex: Phylogenetic re-assessment of pathogens associated with soybean, cucurbits and other field crops. Fungal Biol. 2015, 119, 383-407. [CrossRef] [PubMed]

17. Guarnaccia, V.; Vitale, A.; Cirvilleri, G.; Aiello, D.; Susca, A.; Epifani, F.; Perrone, G.; Polizzi, G. Characterisation and pathogenicity of fungal species associated with branch cankers and stem-end rot of avocado in Italy. Eur. J. Plant Pathol. 2016, 146, 963-976. [CrossRef]

18. Guarnaccia, V.; Crous, P.W. Emerging citrus diseases in Europe caused by Diaporthe spp. IMA Fungus 8 2017, 317-334. [CrossRef]

19. Mostert, L.; Crous, P.W.; Kang, J.-C.; Phillips, A.J.L. Species of Phomopsis and a Libertella sp. occurring on grapevines with specific reference to South Africa: Morphological, cultural, molecular and pathological characterization. Mycologia 2001, 93, 146-167. [CrossRef]

20. Mostert, L.; Kang, J.C.; Crous, P.W.; Denman, S. Phomopsis saccharata sp. nov., causing a canker and die-back disease of Protea repens in South Africa. Sydowia 2001, 53, 227-235. 
21. Udayanga, D.; Liu, X.; McKenzie, E.H.C.; Chukeatirote, E.; Bahkali, A.H.A.; Hyde, K.D. The genus Phomopsis: Biology, applications, species concepts and names of common phytopathogens. Fungal Divers. 2011, 50, 189-225. [CrossRef]

22. Santos, L.; Alves, A.; Alves, R. Evaluating multi-locus phylogenies for species boundaries determination in the genus Diaporthe. PeerJ 2017, 5, e3120. [CrossRef] [PubMed]

23. Yang, Q.; Fan, X.-L.; Guarnaccia, V.; Tian, C.-M. High diversity of Diaporthe species associated with dieback diseases in China, with twelve new species described. MycoKeys 2018, 39, 97-149. [CrossRef] [PubMed]

24. Van Niekerk, J.M.; Groenewald, J.Z.; Farr, D.F.; Fourie, P.H.; Halleen, F.; Crous, P.W.; Halleer, F. Reassessment of Phomopsis species on grapevines. Australas. Plant Pathol. 2005, 34, 27-39. [CrossRef]

25. Gomes, R.R.; Glienke, C.; Videira, S.; Lombard, L.; Groenewald, J.Z.; Crous, P.W. Diaporthe: A genus of endophytic, saprobic and plant pathogenic fungi. Persoonia 2013, 31, 1-41. [CrossRef]

26. Úrbez-Torres, J.R.; Peduto, F.; Smith, R.J.; Gubler, W.D. Phomopsis dieback: A grapevine trunk disease caused by Phomopsis viticola in California. Plant Dis. 2013, 97, 1571-1579. [CrossRef]

27. Dissanayake, A.J.; Liu, M.; Zhang, W.; Chen, Z.; Udayanga, D.; Chukeatirote, E.; Li, X.; Yan, J.; Hyde, K.D. Morphological and molecular characterisation of Diaporthe species associated with grapevine trunk disease in China. Fungal Biol. 2015, 119, 283-294. [CrossRef] [PubMed]

28. Calvo, A.M.; Wilson, R.A.; Bok, J.W.; Keller, N.P. Relationship between secondary metabolism and fungal development. Microbiol. Mol. Biol. Rev. 2002, 66, 447-459. [CrossRef]

29. Chaves, M.M.; Zarrouk, O.; Francisco, R.; Costa, J.M.; Santos, T.; Regalado, A.P.; Rodrigues, M.L.; Lopes, C.M. Grapevine under deficit irrigation: Hints from physiological and molecular data. Ann. Bot. 2010, 105, 661-676. [CrossRef]

30. Abdelrahman, M.; Suzumura, N.; Mitoma, M.; Matsuo, S.; Ikeuchi, T.; Mori, M.; Murakami, K.; Ozaki, Y.; Matsumoto, M.; Uragami, A.; et al. Comparative de novo transcriptome profiles in Asparagus officinali s and A. kiusianus during the early stage of Phomopsis asparagi infection. Sci. Rep. 2017, 7, 2608. [CrossRef]

31. Zhou, J.; Li, X.; Chen, Y.; Dai, C. De novo transcriptome assembly of Phomopsis liquidambari provides insights into genes associated with different lifestyles in rice (Oryza sativa L.). Front. Plant Sci. 2017, 8, 121. [CrossRef] [PubMed]

32. Abdelrahman, M.; Mitoma, M.; Ikeuchi, T.; Mori, M.; Murakami, K.; Ozaki, Y.; Matsumoto, M.; Uragami, A.; Kanno, A. Differential gene expression analysis and SNP/InDel marker discovery in resistant wild Asparagus kiusianus and susceptible A. officinalis in response to Phomopsis asparagi infection. Data Brief 2018, 21, 2117-2121. [CrossRef] [PubMed]

33. Ruiz-Ferrer, V.; Voinnet, O. Roles of plant small RNAs in biotic stress responses. Annu. Rev. Plant Biol. 2009, 60, 485-510. [CrossRef] [PubMed]

34. Sunkar, R.; Li, Y.F.; Jagadeeswaran, G. Functions of microRNAs in plant stress responses. Trends Plant Sci. 2012, 17, 196-203. [CrossRef]

35. Voinnet, O. Origin, biogenesis, and activity of plant microRNAs. Cell 2009, 136, 669-687. [CrossRef]

36. Allen, E.; Xie, Z.; Gustafson, A.M.; Carrington, J.C. microRNA-directed phasing during trans-acting siRNA biogenesis in plants. Cell 2005, 121, 207-221. [CrossRef]

37. Vaucheret, H. Post-transcriptional small RNA pathways in plants: Mechanisms and regulations. Genes Dev. 2006, 20, 759-771. [CrossRef]

38. Budak, H.; Akpinar, B.A. Plant miRNAs: Biogenesis, organization and origins. Funct. Integr. Genom. 2015, 15, 523-531. [CrossRef]

39. Eichmeier, A.; Komínková, M.; Komínek, P.; Baránek, M. Comprehensive virus detection using next generation sequencing in grapevine vascular tissues of plants obtained from the wine regions of Bohemia and Moravia (Czech Republic). PLoS ONE 2016, 11, e0167966. [CrossRef]

40. Baldrich, P.; Campo, S.; Wu, M.T.; Liu, T.T.; Hsing, Y.I.C.; Segundo, B.S. MicroRNA-mediated regulation of gene expression in the response of rice plants to fungal elicitors. RNA Biol. 2015, 12, 847-863. [CrossRef]

41. Soto-Suárez, M.; Baldrich, P.; Weigel, D.; Rubio-Somoza, I.; San Segundo, B. The Arabidopsis miR396 mediates pathogen-associated molecular pattern-triggered immune responses against fungal pathogens. Sci. Rep. 2017, 7, 44898. [CrossRef] [PubMed]

42. Hua, C.; Zhao, J.H.; Guo, H.S. Trans-kingdom RNA silencing in plant-fungal pathogen interactions. Mol. Plant 2018, 11, 235-244. [CrossRef] [PubMed] 
43. The French-Italian Public Consortium for Grapevine Genome Characterization; Jaillon, O.; Aury, J.-M.; Noel, B.; Policriti, A.; Clepet, C.; Casagrande, A.; Choisne, N.; Aubourg, S.; Vitulo, N.; et al. The grapevine genome sequence suggests ancestral hexaploidization in major angiosperm phyla. Nature 2007, 449, 463. [CrossRef]

44. Velasco, R.; Zharkikh, A.; Troggio, M.; Cartwright, D.A.; Cestaro, A.; Pruss, D.; Pindo, M.; Fitzgerald, L.M.; Vezzulli, S.; Reid, J.; et al. A high quality draft consensus sequence of the genome of a heterozygous grapevine variety. PLoS ONE 2007, 2, e1326. [CrossRef]

45. Pantaleo, V.; Szittya, G.; Moxon, S.; Miozzi, L.; Moulton, V.; Dalmay, T.; Burgyan, J. Identification of grapevine microRNAs and their targets using high-throughput sequencing and degradome analysis. Plant J. 2010, 62, 960-976. [CrossRef]

46. Mica, E.; Piccolo, V.; Delledonne, M.; Ferrarini, A.; Pezzotti, M.; Casati, C.; Del Fabbro, C.; Valle, G.; Policriti, A.; Morgante, M.; et al. High throughput approaches reveal splicing of primary microRNA transcripts and tissue specific expression of mature microRNAs in Vitis vinifera. BMC Genomics 2009, 10, 558. [CrossRef]

47. Kozomara, A.; Griffiths-Jones, S. miRBase: Integrating microRNA annotation and deep-sequencing data. Nucleic Acids Res. 2010, 39 (Suppl. 1), D152-D157. [CrossRef]

48. Baránek, M.; Křižan, B.; Ondrušíková, E.; Pidra, M. DNA-methylation changes in grapevine somaclones following in vitro culture and thermotherapy. Plant Celltissue Organ Cult. 2010, 101, 11-22. [CrossRef]

49. Andrews, S. FastQC: A quality control tool for high throughput sequence data. Available online: http: //www.bioinformatics.babraham.ac.uk/projects/fastqc (accessed on 5 November 2019).

50. Dai, X.; Zhao, P.X. psRNATarget: A plant small RNA target analysis server. Nucleic Acids Res. 2011, 39 (Suppl. 2), W155-W159. [CrossRef]

51. Dai, X.; Zhao, P.X. pssRNAMiner: A plant short small RNA regulatory cascade analysis server. Nucleic Acids Res. 2008, 36 (Suppl. 2), W114-W118. [CrossRef]

52. Chen, C.; Ridzon, D.A.; Broomer, A.J.; Zhou, Z.; Lee, D.H.; Nguyen, J.T.; Barbisin, M.; Xu, N.L.; Mahuvakar, V.R.; Andersen, M.R.; et al. Real-time quantification of microRNAs by stem-loop RT-PCR. Nucleic Acids Res. 2005, 33, e179. [CrossRef] [PubMed]

53. Vandesompele, J.; De Preter, K.; Pattyn, F.; Poppe, B.; Van Roy, N.; De Paepe, A.; Speleman, F. Accurate normalization of real-time quantitative RT-PCR data by geometric averaging of multiple internal control genes. Genome Biol. 2002, 3. [CrossRef]

54. Pfaffl, M.W. A new mathematical model for relative quantification in real-time RT-PCR. Nucleic Acids Res. 2001, 29, e45. [CrossRef]

55. Hellemans, J.; Mortier, G.; De Paepe, A.; Speleman, F.; Vandesompele, J. qBase relative quantification framework and software for management and automated analysis of real-time quantitative PCR data. Genome Biol. 2007, 8, R19. [CrossRef]

56. Fan, J.; Liu, J.; Culty, M.; Papadopoulos, V. Acyl-coenzyme A binding domain containing 3 (ACBD3; PAP7; GCP60): An emerging signaling molecule. Prog. Lipid Res. 2010, 49, 218-234. [CrossRef] [PubMed]

57. OIV. OIV FOCUS 2017 Distribution of the World's Grapevine Varieties; International Organisation of Vine and Wine: Paris, France, 2017; p. 54. ISBN 979-10-91799-89-8.

58. Liu, W.; Cheng, C.; Chen, F.; Ni, S.; Lin, Y.; Lai, Z. High-throughput sequencing of small RNAs revealed the diversified cold-responsive pathways during cold stress in the wild banana (Musa itinerans). BMC Plant Biol. 2018, 18, 308. [CrossRef]

59. Ma, X.; Bologna, N.; Palma-Guerrero, J. Small RNA bidirectional crosstalk during the interaction between wheat and Zymoseptoria tritici. bioRxiv 2018, 501593. [CrossRef]

60. Marchi, G. Susceptibility to esca of various grapevine (Vitis vinifera) cultivars grafted on different rootstocks in a vineyard in the province of Siena (Italy). Phytopathol. Mediterr. 2001, 40, 27-36. [CrossRef]

61. Murolo, S.; Romanazzi, G. Effects of grapevine cultivar, rootstock and clone on esca disease. Australas. Plant Pathol. 2014, 43, 215-221. [CrossRef]

62. Rajagopalan, R.; Vaucheret, H.; Trejo, J.; Bartel, D.P. A diverse and evolutionarily fluid set of microRNAs in Arabidopsis thaliana. Genes Dev. 2006, 20, 3407-3425. [CrossRef] 
63. Fahlgren, N.; Howell, M.D.; Kasschau, K.D.; Chapman, E.J.; Sullivan, C.M.; Cumbie, J.S.; Givan, S.A.; Law, T.F.; Grant, S.R.; Dangl, J.L.; et al. High-throughput sequencing of Arabidopsis microRNAs: Evidence for frequent birth and death of MIRNA genes. PLoS ONE 2007, 2, e219. [CrossRef] [PubMed]

64. Moxon, S.; Jing, R.; Szittya, G.; Schwach, F.; Pilcher, R.L.R.; Moulton, V.; Dalmay, T. Deep sequencing of tomato short RNAs identifies microRNAs targeting genes involved in fruit ripening. Genome Res. 2008, 18, 1602-1609. [CrossRef] [PubMed]

65. Xie, Z.; Johansen, L.K.; Gustafson, A.M.; Kasschau, K.D.; Lellis, A.D.; Zilberman, D.; Jacobsen, S.E.; Carrington, J.C. Genetic and functional diversification of small RNA pathways in plants. PLoS Biol. 2004, 2, e104. [CrossRef] [PubMed]

66. Chan, S.W.L.; Henderson, I.R.; Jacobsen, S.E. Gardening the genome: DNA methylation in Arabidopsis thaliana. Nat. Rev. Genet. 2005, 6, 351. [CrossRef]

67. Pantaleo, V.; Vitali, M.; Boccacci, P.; Miozzi, L.; Cuozzo, D.; Chitarra, W.; Mannini, F.; Lovisolo, C.; Gambino, G. Novel functional microRNAs from virus-free and infected Vitis vinifera plants under water stress. Sci. Rep. 2016, 6, 20167. [CrossRef]

68. Raabe, C.A.; Tang, T.H.; Brosius, J.; Rozhdestvensky, T.S. Biases in small RNA deep sequencing data. Nucleic Acids Res. 2013, 42, 1414-1426. [CrossRef]

69. Baev, V.; Milev, I.; Naydenov, M.; Apostolova, E.; Minkov, G.; Minkov, I.; Yahubyan, G. Implementation of a de novo genome-wide computational approach for updating Brachypodium miRNAs. Genomics 2011, 97, 282-293. [CrossRef]

70. Axtell, M.J.; Snyder, J.A.; Bartel, D.P. Common functions for diverse small RNAs of land plants. Plant Cell 2007, 19, 1750-1769. [CrossRef]

71. Bittner-Eddy, P.D.; Beynon, J.L. The Arabidopsis downy mildew resistance gene, RPP13-Nd, functions independently of NDR1 and EDS1 and does not require the accumulation of salicylic acid. Mol. Plant Microbe Interact. 2007, 14, 416-421. [CrossRef]

72. Bhattarai, K.; Wang, W.; Cao, Z.; Deng, Z. Comparative analysis of impatiens leaf transcriptomes reveal candidate genes for resistance to downy mildew caused by Plasmopara obducens. Int. J. Mol. Sci. 2018, 19, 2057. [CrossRef]

73. Rhoades, M.W.; Reinhart, B.J.; Lim, L.P.; Burge, C.B.; Bartel, B.; Bartel, D.P. Prediction of plant microRNA targets. Cell 2002, 110, 513-520. [CrossRef]

74. Zhong, R.; Ye, Z.H. Regulation of HD-ZIP III genes by microRNA 165. Plant Signal. Behav. 2007, 2, 351-353. [CrossRef] [PubMed]

75. Du, Q.; Wang, H. The role of HD-ZIP III transcription factors and miR165/166 in vascular development and secondary cell wall formation. Plant Signal. Behav. 2015, 10, e1078955. [CrossRef] [PubMed]

76. Ohashi-Ito, K.; Kubo, M.; Demura, T.; Fukuda, H. Class III homeodomain leucine-zipper proteins regulate xylem cell differentiation. Plant Cell Physiol. 2005, 46, 1646-1656. [CrossRef] [PubMed]

77. Prigge, M.J.; Otsuga, D.; Alonso, J.M.; Ecker, J.R.; Drews, G.N.; Clark, S.E. Class III homeodomain-leucine zipper gene family members have overlapping, antagonistic, and distinct roles in Arabidopsis development. Plant Cell 2005, 17, 61-76. [CrossRef]

78. Jung, J.H.; Park, C.M. MIR166/165 genes exhibit dynamic expression patterns in regulating shoot apical meristem and floral development in Arabidopsis. Planta 2007, 225, 1327-1338. [CrossRef] [PubMed]

79. Kim, J.; Jung, J.-H.; Reyes, J.L.; Kim, Y.-S.; Kim, S.-Y.; Chung, K.-S.; Kim, J.A.; Lee, M.; Lee, Y.; Kim, V.N.; et al. microRNA-directed cleavage of ATHB15 mRNA regulates vascular development in Arabidopsis inflorescence stems. Plant J. 2005, 42, 84-94. [CrossRef] [PubMed]

80. Dugas, D.V.; Bartel, B. Sucrose induction of Arabidopsis miR398 represses two Cu/Zn superoxide dismutases. Plant Mol. Biol. 2008, 67, 403-417. [CrossRef]

81. Chitarra, W.; Pagliarani, C.; Abbà, S.; Boccacci, P.; Birello, G.; Rossi, M.; Palmano, S.; Marzachì, C.; Perrone, I.; Gambino, G. miRVIT: A novel miRNA database and its application to uncover vitis responses to flavescence dorée infection. Front. Plant Sci. 2018, 9, 1034. [CrossRef]

82. Abdel-Ghany, S.E.; Pilon, M. MicroRNA-mediated systemic down-regulation of copper protein expression in response to low copper availability in Arabidopsis. J. Biol. Chem. 2008, 283, 15932-15945. [CrossRef]

83. Zhang, X.; Zhao, H.; Gao, S.; Wang, W.-C.; Katiyar-Agarwal, S.; Huang, H.-D.; Raikhel, N.; Jin, H. Arabidopsis Argonaute 2 regulates innate immunity via miRNA393*-mediated silencing of a Golgi-localized SNARE gene, MEMB12. Mol. Cell 2011, 42, 356-366. [CrossRef] 
84. Zeng, R.F.; Zhou, J.J.; Liu, S.R.; Gan, Z.M.; Zhang, J.Z.; Hu, C.G. Genome-Wide Identification and Characterization of SQUAMOSA-Promoter-Binding Protein (SBP) Genes Involved in the Flowering Development of Citrus Clementina. Biomolecules 2019, 9, 66. [CrossRef] [PubMed]

85. Weigel, D.; Alvarez, J.; Smyth, D.R.; Yanofsky, M.F.; Meyerowitz, E.M. LEAFY controls floral meristem identity in Arabidopsis. Cell 1992, 69, 843-859. [CrossRef]

86. Bettiga, L.J. Grape Pest Management; University of California Agriculture and Natural Resources (UCANR): Santa Maria, CA, USA, 2013.

(C) 2019 by the authors. Licensee MDPI, Basel, Switzerland. This article is an open access article distributed under the terms and conditions of the Creative Commons Attribution (CC BY) license (http://creativecommons.org/licenses/by/4.0/). 